Anna Jeznach

Department of Nursing and Midwifery Faculty of Health Sciences Collegium Mazovia Innovative University, Siedlce, Poland

\title{
WHY DO NURSING STAFF NEED A CULTURAL KNOWLEDGE?
}

\section{Why do nursing staff need a cultural knowledge?}

\section{Anna Jeznach}

Department of Nursing and Midwifery Faculty of Health Sciences Collegium Mazovia Innovative University, Siedlce, Poland

$$
\text { e-mail:ajeznach@mazovia.edu.pl }
$$

Summary. Cultural knowledge forms the basis of cultural competence and intercultural competence of nursing staff. It is especially important in the face of cultural diversity and individuals from a culturally diverse world.

The aim of the study - to present nursing staff's understanding of the term: cultural knowledge and to identify the meanings given to cultural knowledge in the context of cultural and intercultural competence in the professional practice of nursing staff.

Materials and Methods. The research sample was selected purposively. It consisted of nursing personnel(students of the nursing faculty, second-degree studies at Collegium Mazovia Innovative University in Siedlce, Poland). The research falls within the interpretative paradigm. The research methods used were: desk research and qualitative case study. 8 individual online, asynchronous interviews were conducted. A qualitative "meaning-oriented" analysis with coding and interpretation of meanings was used.

Results. The nursing staff defines the concept of cultural knowledge as: knowledge cultural and religious differences, enabling holistic care of patients; knowledge of the surrounding world, enabling appropriate behaviour towards people from culturally diverse world and tolerance; knowledge of customs, habits of various social groups (nationalities, religions); ability to adapt and function effectively in a culturally diverse environment; development of cultural sensitivity; respect for people; lack of prejudice and stereotypes concerning people from culturally diverse world; spiritual and material achievements of a society. Cultural knowledge, treated as the basis of cultural and intercultural competence, enables: to provide holistic, culturally diverse patient care; respect, tact, openness, appropriate behaviour towards patients from a culturally diverse world (diverse attitudes towards health and illness). It is knowledge that enables the development of empathy, learning, and a broader perspective on people from culturally diverse backgrounds; it eliminates stereotypes and reduces communication barriers; it avoids misunderstandings; it is an intrinsic value and contributes to the awareness of diverse value systems; it enables the understanding of people

\section{Чому медичним сестрам потрібні культурологічні знання?}

\section{Анна Єзнах}

Вища інноваційна школа «Колегіум Мазовія», м. Сєдльце, Польща

Резюме. Культурологічні знання $є$ основою культурних компетенцій медичного персоналу також. Це важливо, коли стикаються із культурним розмаїттям і людьми з культурно різноманітного світу.

Мета дослідження - презентувати розуміння терміну «культурологічні знання» медичним сестрам та виявити значення культурних знань у контексті культурних та міжкультурних компетенцій у їх професійній практиці.

Матеріали і методи. У вибірку для дослідження входили медсестри (студенти медсестринського фракультету другого циклу Вищої інноваційної школи «Колегіум Мазовія» в Сєдльце, Польща). Використовували у ньому такі методи: кабінетне дослідження та якісне дослідження випадку. Було проведено вісім індивідуальних асинхронних онлайн-інтерв'ю, застосували якісний «смислоорієнтований» аналіз із кодуванням і тлумачення значень.

Результати. Медичні сестри визначають поняття «культурологічні знання», як: знання про культурні та релігійні відмінності, що дає можливість цілісного догляду за пацієнтами; знання про навколишній світ, можливість адекватної поведінки відносно людей із культурно різноманітного світу та їх толерантність; знання звичаїв різних соціальних груп (національних, релігійних); здатність адаптуватися та ефективно фоннціонувати в культурно різноманітному середовищі; розвиток культурної чутливості; повага до людей із культурно різноманітного світу; відсутність упереджень і стереотипів щодо людей із культурно різноманітного світу; духовні і матеріальні блага суспільства. Культурологічні знання, які розглядають як основу культурних та міжкультурних компетенцій, дають цілісне, культурно різноманітне обслуговування пацієнтів; повагу, тактовність, відкритість, відповідну поведінку щодо пацієнтів із культурно різноманітного світу (різне ставлення до здоров'я та хвороб).

Висновки. Випадки, представлені у дослідженні, $\epsilon$ аутотелічними (когнітивний аспект і практичні), а 
from culturally diverse backgrounds, reducing uncertainty, frustration, and ethical dilemmas of culturally diverse care.

Conclusions. The presented cases have an autotelic character (cognitive and practical aspect and practical aspects), but they also show a broader context of cultural competence and intercultural competence of nursing staff in culturally diverse care.

Key words: qualitative case study; cultural and intercultural nurses' competences; cultural knowledge.

\section{INTRODUCTION}

In the sphere of public services, especially in the health sector, the important role of cultural and intercultural communication is emphasized (Rubio, 2013). The basis, of this type, of effective communication is cultural knowledge. Taking into account cultural conditions in the work of medical personnel has become a necessity due to ethnic, national, religious diversity (Krajewska-Kułak, Wrońska, Kędziora-Komotowska 2010; Krajewska-Kułak, Guzowski, Bejda, Lankau 2016; Kiszka, Ozga, Mach, Krajewski, 2018; Linka, 2018, pp. 11-13).

Cultural knowledge, according to social and intercultural psychology, is understood as awareness of differences, ability to interact ( Griffin, 2003). It does not mean that: , "we must know everything about a culture or cultures, because it is even impossible. It is important (...) to be aware that people differ in terms of values, beliefs, attitudes, beliefs that influence and shape our way of behaving, thinking and communicating, creating so-called cultural scripts, (...) knowledge is a kind of map, and a map without the ability to read it and use it is of little help" (Mazurkiewicz, 2019). This takes on particular importance in culturally conditioned care. The foundation of this type of care is cultural competence, intercultural competence and cultural intelligence (among others Zalewska-Puchała, Majda, 2012, p.9-12). This is also the case of cultural intelligence (e.g. Ogórek-Tęcza, Kamińska, Matusiak, Skupnik, 2012; Zdziebło, Nowak-Starz, Makieła, Stępień, Wiraszka, 2014; Jeznach, Ruszkowska, 2014; Jeznach, Piekarska, 2018; Majda, Zalewska-Puchała, 2018).

Cultural and intercultural competences are of interest to social sciences: social anthropology and sociology, linguistics, pedagogy, psychology, philosophy, and health sciences. They are complex and multifaceted in nature. Researchers emphasize : "the multiplicity and ambiguity of terms; the lack of expressive competence models; the verification of actual intercultural competences; stereotypical ideas about intercultural learning (...) and the problematic nature of their measurement (Dąbrowa, Markowska-Manista, 2013, pp. 242-254). The following tools for measuring cultural and intercultural competence in nursing are reported in the literature, among others: Cultural Self-Efficacy Scale (CSES); Transcultural Self-Efficacy Tool (TSES); Inventory for Assessing the Process of Comppetency також показано ширший контекст культурних компетенцій медичних сестер, які при наданні допомоги застосовують культурологічні знання.

Ключові слова: якісне дослідження випадку; культурні компетенції; культурологічні знання.

(IAPCC and IAPCC-R); Ethnic Competency Skills Assessment Inventory (ECSAI); Cultural Awareness Scale (CAS); Cultural Competencies Assessment (CCA); Cultural Knowledge Scale (CKS); Cultural Diversity Questionnaire for Nurse Educators (CDQNE); Cultural Competency Instrument (CCl); Cross-Cultural Evolution Tool (CCET); Nurs Cultural Competence Scale (NCCS) ( Loftin et al. 2013. after: Ślusarska, Zarzycka, Majda, Dobrowolska 2017). In Poland, an adaptation of the $\mathrm{CCCl}$ Intercultural Competence Inventory is recommended (Barzykowski, Majdan, Przyłęcki, 2020).

The research presented here referred to theoretical orientations that determined the general attitude towards cultural knowledge (Creswell, 2013, p.85 ). Anthropological definitions of culture (Proser 1987, Tubbs, Moss 1994, after: Kusio 2007, p.24 ), the theory of culture as an iceberg (Hall 2005; Katan1999); anthropological-nursing, transcultural nursing model of Madelaine Laininger called the "Rising Sun" model (Plaszewska-Zywko, 2010, pp.197-205) were considered and cultural and intercultural competence: Milton Bennett's theory of developmental stages of intercultural sensitivity ( Bennet, 1993; Boski, 2010, p. 567-573).

The research objective and theoretical framework enabled the formulation of the main research problem: How do nursing, second degree students understand the term "cultural knowledge" and what meanings do they give to cultural knowledge in the context of cultural and intercultural competence?

The specific research problems were of 1st and 2nd degree constructs ( Schütz, 2008, pp.138-152 ). Level I constructs:

- How do nursing staff understand the term ,,cultural knowledge"?

- How do nursing staff justify the need for cultural knowledge in terms of cultural and intercultural competence?

Level II constructs, on the other hand:

- How to interpret nursing staff narratives of cultural knowledge?

- What themes can emerge in nursing staff narratives justifying the need for cultural knowledge in relation to cultural and intercultural competence?

\section{The aim of the study}

Presentation of the understanding of the notion: cultural knowledge and identification of meanings ascribed 
to cultural knowledge by nursing staff (who are also students of nursing, second degree studies)

\section{MATERIAL AND METHODS}

The samples for the study was selected purposively. It included the nursing staff (students of nursing, second degree studies at Collegium Mazovia Innovative Higher School, Siedlce, Poland). The research was conducted between 15-30.10.21. Two research methods were used: desk research (Makowska 2013, p. 80-103 ) and qualitative case study (Stake, 1997; Yin, 2013). 8 individual online, asynchronous interviews were conducted (Kvale, 2004, p.2, Walentynowicz-Moryl 2017, p. 55-63). Qualitative, "meaning-oriented" analysis with coding and interpretation was used (Kvale, 2012, pp. 171-178). The qualitative research conducted (Creswell, 2013, p. 189-217) falls within the interpretive paradigm (Luszczak, 2011).

\section{Results}

Two interpretive categories were identified in the statements of nursing staff: cultural knowledge (understanding of the concept) and cultural knowledge as a basis for cultural and intercultural competence).

The analysis of narratives (Table 2) concerning the category "cultural knowledge" allowed to assign

Table 1. Characteristics of the cases studied (nursing staff - second degree students)

\begin{tabular}{l|c|c|c|c|c|c}
\hline $\begin{array}{c}\text { No } \\
\text { interview }\end{array}$ & Age & Gender & Seniority & Education & Nationality & $\begin{array}{c}\text { Knowledge } \\
\text { of foreign } \\
\text { languages }\end{array}$ \\
\hline 1. & 40 & $\mathrm{~F}$ & 2 years & higher bachelor degree & Poland & English \\
\hline 2. & 43 & $\mathrm{~F}$ & lack of seniority & higher bachelor degree & Ukraine & Polish, English \\
\hline 3. & 45 & $\mathrm{~F}$ & 28 years & higher bachelor degree & Poland & Russian, English \\
\hline 4. & 39 & $\mathrm{M}$ & 15 years & higher bachelor degree & Poland & English \\
\hline 5. & 37 & $\mathrm{~F}$ & 25 years & higher bachelor degree & Poland & Russian English \\
\hline 6. & 40 & $\mathrm{~F}$ & 11 years & higher bachelor degree & Poland & English \\
\hline 7. & 28 & $\mathrm{~F}$ & 28 years & higher bachelor degree & Poland & English \\
\hline 8. & 46 & $\mathrm{~F}$ & $\begin{array}{c}1 \text { month on the job, } 28 \\
\text { years overall }\end{array}$ & master's degree & Poland & Russian English \\
\hline
\end{tabular}

Source: own research.

Table 2. The concept of "cultural knowledge" - nursing narratives

- (...) means having basic information about other cultures and respecting them (W.1.,N.1)

- to have basic information about another culture, tolerate cultural needs and be able to adapt to the culture of the other person (W. 2.,N.1)

- refers to the analysis and broad cognition of various cultural and religious distinctions. Such cognition enables a better look at a person, family, group through the prism of ethnic and cultural behaviors and beliefs. We live in the times of globalization, open borders, ease of travel increases the migration of people from many countries. Thus, a better understanding of cultural differences of a patient from another country brings a better therapeutic and psychosocial effect. We should develop intercultural sensitivity and educate ourselves about cultural differences. We should respect each individual and remember that the dignity of the human person lies at the basis of human rights (W.3.,N.1)

- knowledge about the world around me from which different cultural nationalities originate, and thanks to this knowledge I know how to behave in order not to offend people with a different culture of life and faith (W.4.,N.1)

- a certain level of knowledge of issues, behaviours, manners, customs, rituals that are characteristic for a given nationality/ community/ religious group (W.5.,N.1)

- (...) means knowing the different forms of behaviour and customs in different cultures. It also means respect. Respecting different behaviour (...) means respecting other people without prejudice or reproducing various permanently fixed stereotypes about the behaviour of an individual or a society from another culture (W.6.,N.1.)

- the ability to function effectively in a culturally different environment from our own. It is the respect for culture and faith of another person. It is understood as the totality of the spiritual and material achievements of the society (W.7.,N.1)

- the preparation for active participation in social life, developing the need and understanding of basic concepts, mechanisms and regularities speaking about the development of culture in society, developing imagination and sensitivity to otherness (...) shaping social, emotional, ethical and aesthetic sensitivity (...) getting to know problems of different cultural circles and diversity of tangible and intangible forms of culture (...) is important for shaping competences necessary for conscious functioning in culture, including intercultural, aesthetic, artistic and interpersonal competences (W.8.,N.1) 
the following notions to it: basic knowledge of cultural and religious differences, enabling holistic care of the patient; knowledge of the surrounding world, enabling appropriate behaviour towards people from culturally diverse world and tolerance; knowledge of behaviours, customs and habits of various social groups: nationalities, religions; ability to adapt and function effectively in a culturally diverse environment; development of cultural sensitivity; respect for people from culturally diverse world; lack of prejudice and stereotypes concerning people from culturally diverse world; spiritual and material spiritual and material achievements of the society.

The analysis of narrations (Table 3) on the category, "cultural knowledge as a basis for cultural and intercultural competence" allowed the following thematic areas to be identified: Enabling holistic, culturally diverse patient care; enabling respect, tact, openness, appropriate behaviour; enabling the development of empathy towards patients from a culturally diverse world with diverse attitudes towards illness, health, death; enabling learning, broadening perspectives on people from a culturally diverse world; bridging stereotypes and reducing communication barriers; avoiding misunderstandings; being a value in itself and contributes to the awareness of diverse value systems; allows for understanding people from a culturally diverse world reducing uncertainty, frustration, ethical dilemmas of culturally sensitive care.

Table 3. Cultural knowledge in the aspect of cultural and intercultural competence - nursing narratives

- is important because of the work with people. The nurse's actions should be directed towards the holistic care of the patient, i.e. care that takes into account every sphere of his/her life. A nurse is characterized by above-average empathy and respect towards patients, however it is not easy when they do not know about other cultures. Certain words, gestures, or medical actions, although they are intended to help the patient, may be received badly if in a given culture they are an expression of breaking customs or rules. Therefore, it is important that a person whose work is based on interpersonal contacts has at least a basic knowledge about other cultures (W.1.,N.2)

- as more and more people move, travel, Polish nurses meet people from other cultures, with other customs, from other countries, with other religions, with other approach to illness, health, birth, death etc. Cultural knowledge will help the nurse to adapt quickly to each patient, tolerate and help (W.2.,N.2)

- when caring for a patient with a different cultural, religious or ethnic background, we must not be stereotyped into thinking that it is the patient who has to adapt to the rules of a particular country. This is wrong thinking, and it goes against with the basic law of respect for human rights. When caring for patients with different cultural and religious values, it is important to interview them or their families and obtain the necessary information to provide holistic care that meets their physical, mental, social and spiritual needs. We may encounter obstacles in our care, mainly language barriers and lack of knowledge, but with a little will on our part we can overcome these obstacles. We should remember to approach the culturally different patient with openness and respect (W.3,N.2)

- we need it to behave skilfully, to respect and observe certain values. Thanks to cultural knowledge we can avoid unpleasant situations connected with a different culture (W.4.,N.2)

- is necessary in everyday work of a nurse, because through open borders, migration in our profession we can meet different people, coming from different cultures, belonging to different religions, professing different principles and views. This knowledge will allow us to respect him/her as a human being, especially at the time of illness and suffering (W.5.,N.2)

- it helps the nurse to be more empathetic. It helps us to understand other people's habits and behaviours, sometimes different from our own, but not inferior. (...) It helps us to be more empathetic. In my opinion it makes us perceive the patient in a different way, it makes us understand his behaviour and rules of living in the society better. Such knowledge makes us more competent towards a patient from a different culture. It allows us to see another person as someone who, despite of religious differences, also deserves respect, understanding, listening and equal treatment. In my opinion, we should treat others as we would like to be treated ourselves regardless of religion, culture or other norms and customs (W.6.,N.2.)

- patients who experience nursing care that is not reasonably consistent with their beliefs, values, and concern for life will show signs of cultural conflict, stress, and ethical or moral concerns. Cultural differences may create some barriers in medical-patient interactions. It should be considered as a value because both parties can get to know each other and learn. Diversity allows to look at the world more broadly and assess the surrounding reality from a different perspective. Knowledge of cultural phenomena reduces uncertainty and frustration for both the nurse/midwife and the patient. It helps to predict the clients' behaviours, by putting their customs and practices into some logical models (W.7.,N.2)

- it is supposed to serve us as a kind of map in our work with patients. However, this map, that is our knowledge about culture without the ability to read it and use it, is of little help (...) a nurse should be able to empathize with another person's situation, to be able to react (...) I think that in order to be able to read such a map and use it, we need attentiveness. Mindfulness is a kind of bridge here, a link between knowledge and behaviour (W.8.,N.2) 


\section{RESULTS AND DISCUSSION}

There are many studies in the literature, both quantitative and quantitative in nature, on issues related to multicultural and interculturalism in nursing practice. Of particular interest is the study of cultural competence, research on the influence of religion on aspects of medical care, standards of nursing care towards patients from a culturally diverse world, attitudes towards people from a culturally diverse world, stereotypes towards people representing culturally diverse groups; medical care for people of different religions (e.g. Chałaś-Małdańska, Bieniak, Machuł 2017; Majda, Zalewska-Puchała, Barczyk 2013; Zdziebło, NowakStarz, Makieła 2014; Pruszyński, Putz 2012; Kostka, Kruniszewska, Borodicz 2017, Kiszka, Ozga, Mach, Krajewski 2017)

The qualitative analysis and interpretation carried out showed that having cultural knowledge is essential for the cultural and intercultural competence of nursing staff and thus for the holistic care of patients. It may contribute to quantitative research and thus contribute to research in the area of multicultural nursing ${ }^{1}$ (more commonly referred to as

\section{LITERATURE}

1. Bennett MJ. Towards ethnorelativism: Adevelopmental model of intercultural sensitivity. In R.M. Paige (Ed.), Education for the intercultural experience. Yarmouth, ME: Intercultural Press; 1993.

2. Barzykowski K, Majda A, Przyłeck P. Polish adaptation of the Intercultural Competence Inventory: tool presentation. Nursing. 2020. XXIw.;19,1(70). Available from:https:// ruj.uj.edu.pl/xmlui/bitstream/handle/item/155140/ barzykowski_majda_przylecki_polish_adaptation_ of_the_cross-cultural_competence_inventory_2020. odt? sequence $=2 \&$ isAllowed $=y$

3. Boski P. The cultural framework of social behavior. Handbook of intercultural psychology. Warsaw: Wydawnictwo Naukowe PWN; 2009.

4. Chałaś-Małdańska J, Bieniak M, Machuł M. Research on multiculturalism in nursing practice. A review of Polish nursing literature. 2017. Available from: https://www. researchgate.net/journal/Journal-of-Education-Health-andSport-2391-8306

5. Creswell J. Research design. Qualitative, quantitative and mixed methods. Kraków: Jagiellonian University Publishing House; 2013

6. Dabrowa E, Markowska-Manista U. Teachers' competences in intercultural education. In: J. Muszyńska, W. Danilewicz, T. Bajkowski (ed. nauk.), Intercultural transcultural nursing in English literature). Future researchers may pursue similar themes by examining levels of cultural and intercultural competence with standardized research tools or by focusing on qualitative case studies.

\section{CONCLUSIONS AND PROSPECTS FOR FUR- THER RESEARCH}

1. The presented cases have an autotelic character, both cognitive aspect (persons of different age, Polish and Ukrainian nationality, with different work experience, with different knowledge of foreign languages) and practical aspect (they concern taking professional care conditioned by culture;

2. The cases presented here demonstrate the broader context of the importance of cultural and intercultural competence of nursing staff in culturally driven care;

3. There is a need for interdisciplinary research on multicultural and intercultural issues in medical care with particular emphasis on examining the level of cultural and intercultural competence of nursing staff;

4. Attention should be paid to the intercultural preparation of teachers teaching nursing courses.

competences as capital of multicultural communities. Warsaw: Wydawnictwo Akademickie „Żak"; 2013.

7. Griifin E. Basics of social communication. Gdańsk: GWP; 2003.

8. Hall TE. Polish editio (1997, 2005). The hidden dimension, transl. T. Hołówka. Warsaw: Warsaw Literary Publishing House; 1966.

9. Jeznach A, Piekarska R. Intercultural competence of nursing students, second degree studies. Social Dissertations. 2018;12(2): 38-50.

10. Jeznach A, Ruszkowska M. Intercultural communication competence among nursing students - reality or illusion. In: Diagnostyka i metodyka psychopedagogiczna w warunkach wielokulturowości. Warsaw: Wydawnictwo Akademickie ,„Żak"; 2014.

11. Katan D. Translating Cultures, Manchester: St. Jerome Publishing; 1999.

12. Kiszka J, Ozga D, Mach A, Krajewski R. Providing assistance to culturally different patients against the background of contemporary problems of population migration; 2018. Available from: https://docplayer.pl/112130752Udzielanie-pomocy-pacjentom-odmiennym-kulturowo-na-tlewspolczesnych-migracji-ludnosci.html (18.11.2021)

13. Kostka A, Krzemińska S, Borodzicz. Multicultural in nursing - differences in caring for a Muslim. Journal of

\footnotetext{
${ }^{1}$ Multicultural nursing is included in the Polish formal medical education from 2019, at the second level of education, in accordance with the Regulation of the Ministry of Science and Higher Education on the educational standards preparing for the professions of doctor, dentist, pharmacist, nurse, midwife, laboratory diagnostician, physiotherapist and paramedic of 21 August 2019, Annex 4 (Journal of Laws 2019, item 1573). Previously, intercultural education was possible within social and humanities subjects.
} 
Education, Health and Sport. 2017;7(5): 67-75. Available from: http://ojs.ukw.edu.pl/index.php/johs/article/view/4433

14. DOI http://dx.doi.org/10.5281/zenodo.569900

15. Krajewska-Kułak E, Guzowski A, Bejda G, Lankau A. The patient ,culturally different" calling for medical care. Poznań: University of Białystok, SILVA RERUM Scientific Publishing House; 2016.

16. Krajewska-Kułak E, Wrońska I, KędzioraKornatowska K. Problems of Multiculturalism in Medicine. Warsaw: Wydawnictwo Lekarskie PZWL; 2010.

17. Kusio U. Ed. Polyphony, dialogue and clash of cultures. Anthology of texts from intercultural communication. Toruń: Wydawnictwo Adam Marszałek; 2007.

18. Kvale S. Inter Views: an introduction to qualitative research interviewing. Bialystok: Trans Humana; 2004.

19. Kvale S. Conducting interviews. Warsaw: Wydawnictwo Naukowe PWN; 2012.

20. Link A. Intercultural competence of socia service workers. Szczecin: Wydawnictwo Uniwersytetu Szczecińskiego; 2019.

21. Luszczak W. Normative and interpretative paradigm in pedagogical research. Sosnowiec: Wyższa Szkoła Humanitas, Oficyna Wydawnicza „Humanitas"; 2011. Available from: http://www.sbc.org.pl/Content/22112/ luszczuk.pdf (07.03.21)

22. Majda A, Zalewska-Puchała J, Barczyk E. Stereoptypes and prejudices towards culturally different people in the consciousness of nursing students. Problemy pielęgniarstwa. 2013;21(2): 187-94.

23. Majda A, Zalewska-Puchała J. Cultural competence and cultural intelligence in nursing. Pielęgniarstwo polskie. 2018;2(69): 196-203.

24. Makowska M. Ed. Stored data analysis. A guide for students. Warsaw: Wydawnictwo Naukowe „Scholar"; 2013

25. Mazurkiewicz M. Why do we need cultural intelligence (CQ) and what role does mindfulness play in developing it? 2019. Available from: https://www.czasopismomindfulness. $\mathrm{pl} /$ artykul/po-co-nam-inteligencja-kulturowa-cq-i-jaka-roleodgrywa-uwaznosc-w-jej-rozwijaniu
26. Ogórek-Tęcza B, KamińskaA, MatusiakM, SkupnikR. The influence of empathy level on the perception of nursepatient relationship from another cultural area. Nursing XXI Century. 2012;4(41): 61-3.

27. Pruszyński JJ, Put J. Cultural determinants of Buddhists' needs during illness and the last period of life. Problemy Higieny i Epidemiologiiю 2012;93(1): 183-8.

28. Regulation of the Minister of Education and Higher Education on the educational standards preparing for the professions of doctor, dentist, pharmacist, nurse, midwife, laboratory diagnostician, physiotherapist and paramedic of 21 August 2019; Annex 4 (Journal of Laws 2019, item 1573).

29. Rubio M. Immigrants and intercultural communication in the sphere of public services in Poland. Kraków: Zakład Wydawniczy „NOMOS"; 2013

30. Schütz A. On the multiplicity of worlds. Kraków: Zakład Wydawniczy ,,NOMOS"; 2008.

31. Ślusarska, B, Zarzycka D, Majda A, Dobrowolska B. Cultural competence in nursing: basis of conceptualization and scientific measurement tools. Nursing. 2017; XXI,(4)16: 40-5.

32. Stake RE. A qualitative case study. In: N. K. Denzin, Y. Denzin (ed.), (2009) Methods of qualitative research, Volume I, Warsaw: PWN; 1997.

33. Walentynowicz-Moryl. Individual online interview an asynchronous technique. In: Studies in social sciences No.3. University of Zielona Góra; 2017.

34. Yin RK, transl. J. Gilewicz. Case study in research. Design and methods. Kraków: Jagiellonian University Publishing House; 2013.

35. Zalewska-Puchała J, Majda A. Cultural determinants of nursing. Transcultural nursing. Part 1.Intercultural communication. W: ,ad vocem" Pismo Małopolska Okręgowej Izba Pielęgniarek i Położnych, Kraków. 2012;103: 9-12.

36. Zdziebło K, Nowak-Starz G, Makieła E, Stępień R, Wiraszka G. Intercultural competence in nursing. Problemy pielęgniarstwa. 2014;22(2): 367-372. 